研究ノート

\title{
ムラサキイガイの有効利用にょる港湾の 富栄養化防止に関する研究
}

\section{1.緒言}

閉鎖性海域である大阪湾における窒素やリンの濃 度は，10年程前から横ばい状態であるといわれてい $る^{1)}$. また化学的酸素要求量 (COD) の環境基準の達 成状況は，ここ数年では東京湾は横ばい，瀬戸内海 は悪化しており，環境庁は，第 4 次総量規制で COD の総量をさらに $10 \%$ 程度削減し，さらに第 5 次規制 では窒素とリンも総量規制の対象に加えたいとして いる.

海水中の有機污濁物質・窒素・リン（以下富栄養 化物質と呼ぶ）を除去する水質浄化法として, 富栄 養化物質を海水中で処理する方法と生物などに吸収 させ，これを回収後陸上で処理する方法とが考えら れる. 前者の例として, 石積み浄化堤 ${ }^{2 \sim 4)}$ や鉛直壁の ポーラスコンクリート ${ }^{5}$ 表面に定着した生物膜によ り有機污濁物質を分解する試みが行われている.

一方，港湾の鉛直壁の中・下層には，ムラサキイ ガイが大量に付着生息している.ムラサキイガイは, 海水中の懸濁態窒素を取り込み, 富栄養化を防止し, 水質を浄化する働きを持つが，夏期，高温にさらさ れると体温の上昇及び体水分の蒸発をまねき, 活力 の低下または死亡を引き起こし，大量に脱落する. 海底に落下したムラサキイガイは分解され, 体内に 取り込んだ窒素が再び海水中に溶け出し，鉛直壁付 近の水質を悪化させる原因にもなっているといわれ ている ${ }^{6}$.これを防ぎ, ムラサキイガイの水質浄化能 を活用するために, 水深 $2 \sim 3 \mathrm{~m}$ 層にテラス状の平 坦面を有する護岸や緩傾斜護岸を鉛直壁に代えて設 置することが提案されている6). しかし, すでに多数 存在する鉛直壁を取り壊したり，新たにこれらを設 置するには, 莫大な経費がかかる. 細川勇はムラサキ

*神戸商船大学 Keiichi FUKUSHI, Masayoshi KUBO ***神戸女子短期大学 Kazuo HIIRO

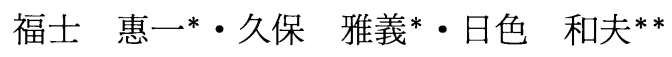

イガイなどの浄化作用について検討しているが，そ の中でムラサキイガイなどを陸上に取り上げること を考慮する必要があると指摘している．後者の水質 浄化法として, 窒素を取り込んだムラサキイガイを 脱落する前に回収すれば，鉛直壁の積極的利用によ る港湾の水質浄化が可能となると思われる. しかし この場合, 回収したムラサキイガイを放置すれば腐 敗臭を放つため, その処理が問題となる. 野菜の肥 料として必要な 5 大要素は, 窒素, リン酸, カリウ ム, カルシウム, マグネシウムであるが8), ムラサキ イガイには，これら要素がかなり含まれている9)。そ こで著者らは, 回収したムラサキイガイを野菜など の肥料として利用することを考えた. 最近, 家庭で の生ゴミを発酵処理し，肥料化する目的で $\mathrm{EM}^{10)}$ と いうものが市販されている。本研究では, (1)単純化 した閉鎖性海域モデルを用い，ムラサキイガイの水 質净化効果を評価する(2)回収したムラサキイガイの 腐敗による悪臭を軽減するために，これを $\mathrm{EM}$ を用 いて発酵処理し，ムラサキイガイの肥料としての有 用性について調べる，以上により，ムラサキイガイ の港湾浄化への活用可能性について検討することを 目的とする.

\section{2. 実 験}

鉛直壁よりムラサキイガイを採取し, 発酵処理後, これを肥料として野菜を栽培した。野菜の生長状況 を観察し，収穫した野菜の重さと含まれるカルシウ ムあるいはビ夕ミン $\mathrm{C}$ 量を測定し，市販の野菜のそ れらと比較した。

\section{1 ムラサキイガイの採取}

神戸商船大学構内港（ポンド）の岸壁に, 写真 1 に示すように付着していたムラサキイガイをボート 上より手で採取した。採取したムラサキイガイは, 長さ3.6〜 7.5cm，幅 $2.0 \sim 3.6 \mathrm{~cm}$ ，重さ $5 \sim 50 \mathrm{~g}$ であ 


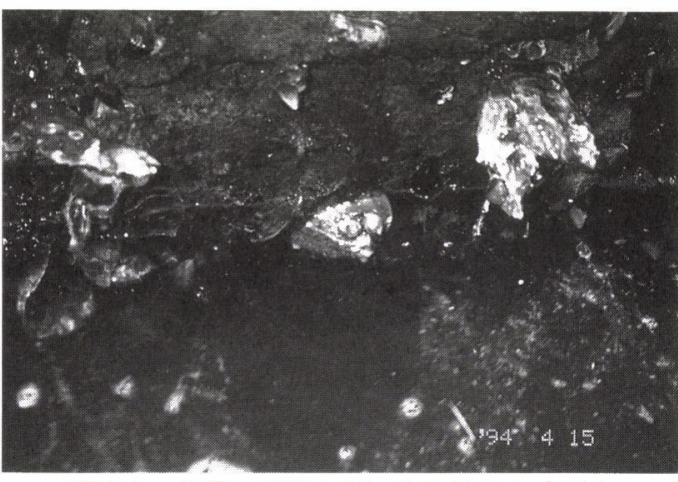

写真 1 岸壁に付着しているムラサキイガイ

った.

\section{2 土㙵の調製}

採取したムラサキイガイを水道水でよく洗浄後, ダンボール上でハンマーを用いて粉砕した。適量の 粉砕したムラサキイガイと市販の発酵堆肥化材 EM をビニール袋に交互に入れ,ビニール袋の口を閉じ， ふた付きのポリバケツに入れて空気に触れないよう にしておいた。ポリバケツを室温 $\left(24 \sim 28^{\circ} \mathrm{C}\right)$ で約 2 週間放置し，ムラサキイガイを発酵させた。つい で発酵したムラサキイガイを土の間にサンドイッチ 状に入れ，さらに約 2 週間放置した。なお EM を加 えなかったムラサキイガイは，粉砕後すぐに土の間 に入れた。

栽培土壤として(1) EM で処理したムラサキイガ イを層状に加えたもの(2)移植直前に(1)をかき混ぜた もの(3)末処理のムラサキイガイを層状に加えたもの (4)ムラサキイガイを加えていないもの，の4 種類を 調製した。

\section{3 野菜の栽培}

野菜として，暑さに強く，土質も特に選ばないチ ンゲンサイと長期間栽培できるホウレンソウを選ん だ。苗床で一様に生育した苗を発芽後約 2 週間で各 プランターに 5 本ずつ移植した。移植後約 1 カ月半 で収穫し，重さを測定した。なおムラサキイガイ採 取から種まきまでの期間は約 3 週間であった。

\section{4 カルシウム及びビタミンCの測定}

チンゲンサイ，ホウレンソウはそれぞれカルシウ ム及びビタミンCを多く含む野菜として知られてい る。そこでムラサキイガイの肥料としての有用性評 価の尺度の一つとして, 栽培したチンゲンサイやホ ウウレンソウ中に含まれるカルシウムあるいはビタミ ンC 量を測定し, 市販野菜中のこれらの含有量と比
較した。チンゲンサイからのカルシウムの抽出は, 石井らの方法 ${ }^{11)}$ ，ホウレンソウからのビタミンCの 抽出は福場らの方法 ${ }^{12}$ に準じて行った。またそれら の測定は, 著者らが確立した条件 ${ }^{13,14}$ を用い, キャピ ラリーゾーン電気泳動法によった。

\section{3. 結果と考察}

\section{1 水質浄化効果}

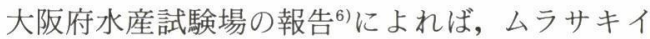

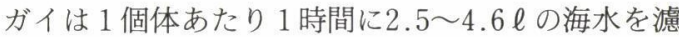
過し，その中に含まれる懸濁態有機物を餌として摄 取するといわれている。 また同試験場が，大阪湾尾 崎地先の鉛直壁における1991年 5 月より 9 月にかけ てのムラサキイガイ個体群の窒素収支を検討した結 果，ムラサキイガイ分布層 $1 \mathrm{~m}^{2}$ 当たり約 $65 \mathrm{gN}$ の窒 素がムラサキイガイの体内にトラップされたとして いる.

そこで図一 1 に扔いて斜線で示したように，船た まり（長さ $\mathrm{L}$, 幅 $\mathrm{B}$, 水深 $\mathrm{h}, 0 \leqq \alpha<1$ ) の鉛直壁 の各面で，ムラサキイガイが深さ $1 \mathrm{~m}$ にわたり付着 していると仮定する. 図中の $\alpha$ は船だまりの閉鎖性 を表す。船だまり内の上記期間中の懸濁態窒素の総 トラップ量を $\mathrm{N}(\mathrm{kgN})$ とすると,

$$
\mathrm{N}=0.065 \times\{2 \mathrm{~L}+(1+\alpha) \mathrm{B}\} \times 1
$$

となる，h を一定とし， B， L， $\alpha$ を変化させた場 合のNの值を表 1 に示す。これより以下のことが言 える。

1 ）他の条件は一定で $\alpha$ が増加した場合，Nは増加 する。すなおち水域の閉鎖性が強まる場合でも，浄 化能力は上がる.

2) 船だまりの容積及び $\alpha$ が一定の場合には，L> Bの方がNは大きい.

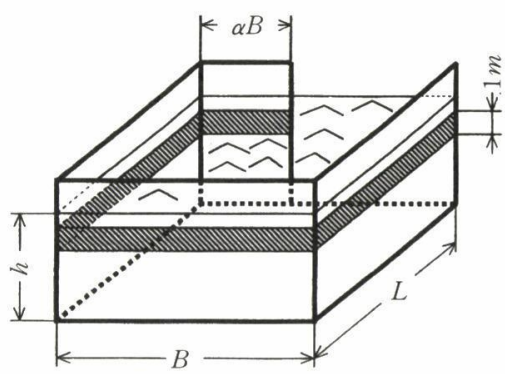

図一 1 船だまりモデル 
表 1 ムラサキイガイの水質浄化効果

\begin{tabular}{ccccc}
\hline & $\mathrm{B}(\mathrm{m})$ & $\mathrm{L}(\mathrm{m})$ & $\alpha$ & $\mathrm{N}(\mathrm{kgN})$ \\
\hline 1 & 350 & 250 & 0.00 & 55 \\
2 & 350 & 250 & 0.25 & 61 \\
3 & 350 & 250 & 0.50 & 67 \\
4 & 350 & 250 & 0.75 & 72 \\
5 & 250 & 350 & 0.50 & 70 \\
6 & 100 & 250 & 0.50 & 42 \\
7 & 200 & 250 & 0.50 & 52 \\
8 & 500 & 250 & 0.50 & 81 \\
9 & 350 & 100 & 0.50 & 47 \\
10 & 350 & 400 & 0.50 & 86 \\
11 & 350 & 500 & 0.50 & 99
\end{tabular}

3 ）他の条件は一定で，B，Lが増加した場合，N は増加する。

4 ) 大阪府の渚近傍における海水中の懸濁態窒素濃 度の平均值 $0.18 \mathrm{mgN} / \mathrm{l}^{6)}$ と表 1 の船だまり $1 （ \mathrm{~h}=$ $4 \mathrm{~m}$ とする.)内の海水量とから，ある瞬間における 懸濁態窒素の総量を計算すると $63 \mathrm{kgN}$ となる. $\mathrm{N}=$ $55 \mathrm{kgN}$ であるから，水域浄化に関してこの方法は十 分期待できる.

なお大阪湾におけるムラサキイガイの繁殖密度, 水深方向の分布及びその生長速度などについては, 大阪府水産試験場により詳しく調査されている ${ }^{15)}$.

\section{2 肥料としての有用性}

図一 2 に示すように，移植後約 2 週間まではムう サキイガイを含まない土袞で栽培したチンゲンサイ は，ムラサキイガイを含む土壌で栽培したものより

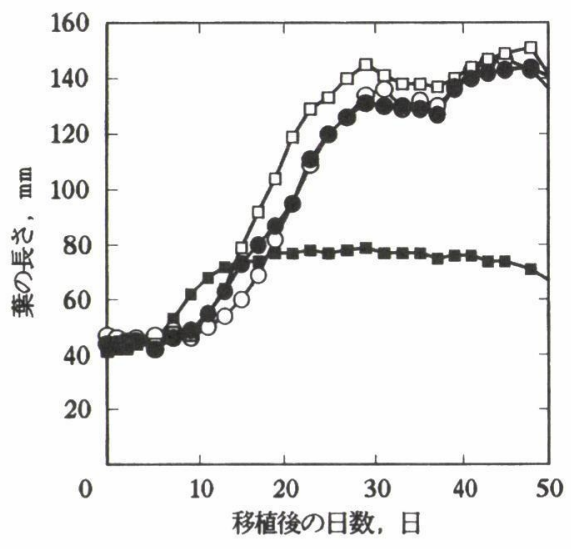

図一 2 チンゲンサイの生長速度

：ムラサキイガイ $+\mathrm{E} M$ M (層)

$\square$ ：ムラサキイガイ + E M M (混合

：ムラサキイガイ(層)

口：ムラサキイガイなし

葉の長さ, $\mathrm{mm}$ 移植後の日数, 日
生育が良かった。その後, 前者は肥料不足のためほ とんど生長しなかったが，後者は 1 ケ月後まで急激 に生長し,さらに少しずつ生長した。 写真 2 に収穫 直前のチンゲンサイを示す。表 2 に示すように，後 者の収穫時の重さ及び含まれるカルシウム量は, 市 販のものとほぼ同じであった。なお $\mathrm{EM}$ 用いた場 合と用いなかった場合とでは，チンゲンサイの生長 速度, 収穫後の重さ及びカルシウム含有量に差はみ られなかった。また表 3 に示すように，ムラサキイ ガイを含む土壤で栽培したホウレンソウの重さ及び ビタミンC含有量は,それぞれ市販のものの1.6及び 2.6倍であった.今回は悪臭防止の目的で EMを用い たが，その効果については定量的な検討をしていな いのではっきりしたことはわからない.

\section{4. 結語}

実験及び考察より得られた結果を要約すると以下

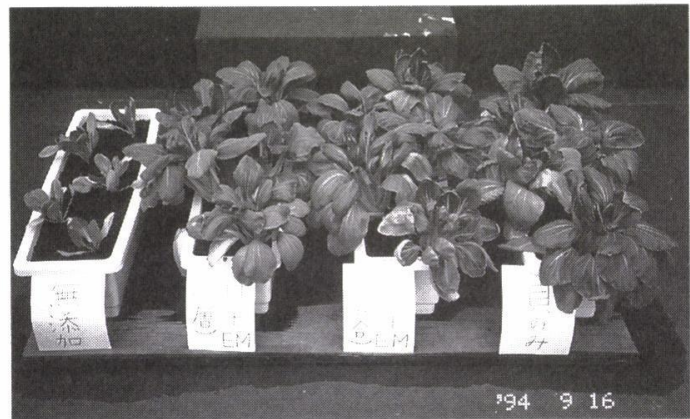

写真 2 収穫直前のチンゲンサイ

左からムラサキイガイなし，ムラサキイガイ $+\mathrm{EM}$ (層)，ムラ サキイガイ $+\mathrm{EM}$ (混合)，ムラサキイガイ(層)の各土壤で栽培 したチンゲンサイ

表 2 収穫したチンゲンサイの重さとカルシウム量

\begin{tabular}{lrc}
\hline \multicolumn{1}{c}{ チンゲンサイ } & 重さ $(\mathrm{g})$ & $\mathrm{Ca}(\mathrm{mg} / \mathrm{l00 \textrm {g }})$ \\
\hline ムラサキイガイ+EM(層) & 113 & 146 \\
ムラサキイガイ+EM(混合) & 110 & 105 \\
ムラサキイガイ(層) & 143 & 123 \\
ムラサキイガイなし & 7 & - \\
市販チンゲンサイ & 139 & 136 \\
\hline
\end{tabular}

表 3 収穫したホウレンソウの重さとビタミンC量

\begin{tabular}{lcc}
\multicolumn{1}{c}{ ホンレンソウ } & 重さ $(\mathrm{g})$ & ビタミン C $(\mathrm{mg} / 100 \mathrm{~g})$ \\
\hline ムラサキイガイ+EM(層) & 59 & 80 \\
ムラサキイガイなし & 7 & - \\
市販ホウレンソウ & 38 & 31 \\
\hline
\end{tabular}


のようになる。

1) ムラサキイガイの水質浄化効果は，水域の閉鎖 性が強まるほど大きいので，この方法は閉鎖性海域 の浄化に関して理にかなっている.

2 ）ムラサキイガイは野菜等の肥料として有用であ る.

3 ） ムラサキイガイを添加して栽培したチンゲンサ イと市販のチンゲンサイ中のカルシウム量の間に差 は認められなかった。これはチンゲンサイのカルシ ウム攝取能力に限界があるものと理解される。

以上の結果, 鉛直壁に付着したムラサキイガイを 回収し, 肥料として有効利用することにより, 鉛直 壁を港湾の環境浄化に積極的に活用できる可能性が あることが明らかとなった。

今後さらに検討すべき課題として，ムラサキイガ イに含まれる重金属類の調査 ${ }^{16,17)}$, 鉛直壁から効率 よくムラサキイガイなどを採取する方法及びその肥 料化法の開発 ${ }^{18)}$ などがあげられる.

\section{参 考 文 献}

1) 大阪湾シンポジウム編, “大阪湾の本” : p. 30, どうなる? 大阪湾くらしと器境を考えるシンポジウム，大阪 (1994).

2 ) 辻 博和, 喜田大三, 藤井慎吾, 石垣 衛, 宮岡修二, 小 林 真: “石積み浄化堤による海水浄化工法の開発（その 1) ”, 大林組技術研究所報, No. 49, 121 124 (1994).

3 ) 藤井慎吾, 喜田大三, 辻 博和, 宮岡修二 : “石積み浄化 堤による海水浄化工法の開発 (その 2 )”, 大林組技術研究
所報, No. 50，107 112 (1995).

4 ) 宮岡修二, 辻 博和, 石垣 衛, 喜田大三, 藤井 慎吾, 小 林 真： “石積み浄化堤による海水浄化工法の開発 (その) “ 3 )”, 大林組技術研究所報, No. 51, 99〜 104 (1995).

5 ) 大阪府立水産試験場, 近畿大学編, 河合 章, 来田秀雄 : “渚の環境構造とその役割に関する調査研究報告書”, 大 阪府立水産試験場, 125 (1993).

6 ) 大阪府立水産試験場, 近畿大学編, 矢持 進, 佐野雅基, 有山啓之: “渚の環境構造とその役割に関する調查研究報 告書”, 大阪府立水産試験場, 108 (1993).

7 ) 細川恭史：沿岸海洋研究ノ一ト, Vol. 29, No. 1, 28 (1991).

8 ）鈴木早苗：“野菜のつくり方”, p. 94, 成美堂出版, 東京 (1993).

9 ）香川 綾 監修: “四訂食品成分表”, p. 148, 女子栄養大 学出版部, 東京 (1994).

10）比嘉照夫：“地球を救う大変革”, p. 12, サンマーク出版, 東京 (1993).

11) 石井裕子, 滝山一善 : 第54回分析化学討論会講演要旨集, 707 (1993).

12）福場博保, 津田淑江：栄養と食糧, Vol. 32, No. 6, 383 (1979).

13) K. Fukushi, K. Hiiro : Fresenius' Journal of Analytical Chemistry, in press.

14）福士惠一, 竹田さほり, 脇田慎一, 山根昌隆, 東 国茂, 日色和夫：第57回分析化学討論会講演要旨集, 266(1996).

15）大阪府立水産試験場, 近畿大学編, 鍋島靖信, 矢持 進, 有山啓之, 睦谷一馬, 日下部敬之, 佐野雅基：“渚の環境 構造とその役割に関する調査研究報告書”, 大阪府立水産 試験場, 27 (1993).

16）岡本研作, 不破敬一郎：環境研究, No. 50, 108 (1984).

17) T. Higashiyama, H. Shiraishi, A. Otsuki, S. Hashimoto : Marine Pollution Bulletin, Vol. 22, No. 12, 585 (1991).

18）三村治夫, 前田勝正, 東 徹勇, 永田進一：環境技術, Vol. 24, No. 9, 13 (1995).

新刊图書 10 \%

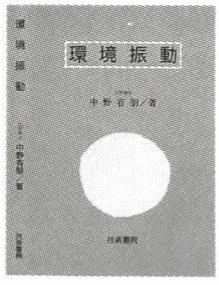

目次

第 1 章 環境振動の基礎

1. 環境振動とは

2. 振動とは

3. 振動に関する物理的諸量

4. 振動に関する感覚的諸量

5. 環境振動の表し方

第 2 章 環境振動の測定

\section{環境 振動}

1. 振動レベルの測定器

2. 振動レベルの測定方法

3. 振動レベルの定め方

4. 周波数分析器と周波数分析

5 . 改定振動の測定

第 3 章 環境振動の評価

1. 環境振動の評価値

2. 環境振動の影響と振動レベル
著者 中野 有朋

定価 2,678円

株技術書院

TEL03-3265-3371 